\title{
CHINESE ENGAGEMENT IN LATIN AMERICA AND EUROPE: INSIGHTS FOR ROMANIA
}

\author{
Professor R. Evan ELLIS, Ph.D. ${ }^{223}$
}

\begin{abstract}
This paper examines Chinese commercial, political, and security engagement with Latin America and the Caribbean, comparing it with similar engagement in Europe. It finds evidence that PRC engagement globally is driven by a strategy focused on re-orienting the world to the economic benefit of the PRC, with nonetheless important political, institutional, and security engagement in support of these objectives and the consequences of their pursuit. It finds common elements in China's pursuit of secure sources of supply, markets and technology across regions, its use of the PRC government supporting roles, with differences reflecting the governance and political structure of each partner, the economic opportunities available, and the imperatives of geography. It finds that PRC "soft power" over political and business elites in both regions is significant, based more in the expectation of benefit than an alignment of values, and thus can coexist with mistrust of the PRC. It finds that Europe can not only gain insights from examining Chinese engagement in Latin America, but that engagement impacts Europe directly through the roles of its companies as both competitors and partners of European ones in the region, and through intraregional supply chains and the flows of funds through mergers and acquisitions by China of stakes in European companies.
\end{abstract}

Keywords: PRC, China, Latin America, Belt and Road, BRI, Infrastructure, Security Engagement.

In recent months, the government of Romania has notably pushed back against political and economic courtship from the People's Republic of China (PRC), in turning away from the PRC for a badly needed nuclear energy project, 5G telecommunications network, and participation in the 2021 Europe-wide " $17+1$ " forum with the PRC. Romania's experience calls attention to patterns of Chinese courtship and resistance to it that are common both across Europe, and also in other parts of the globe.

From the perspective of Washington, PRC engagement with Europe is often analyzed in very different terms than Chinese activities in Latin America, and by very different groups of scholars. Analysis of China-Europe engagement in the US most frequently focuses on the EU and PRC interest in its markets and technology. China-Latin America engagement, by contrast, frequently

\footnotetext{
${ }^{223}$ The author is Latin America Research Professor for the U.S. Army War College Strategic Studies Institute. Dr. Ellis previously served as on the Secretary of State's Policy Planning Staff $(\mathrm{S} / \mathrm{P})$ with responsibility for Latin America and the Caribbean (WHA), as well as International Narcotics and Law Enforcement (INL) Issues. The opinions expressed herein are strictly his own.
} 
emphasizes PRC pursuit of commodities and influence in the U.S. "backyard"224. While both perspectives are partially valid, comparing PRC engagement with Europe versus Latin America yields both unexpected parallels, as well as useful insights from both the contrasts between Chinese engagement in the two regions, and the interdependencies between them in their China relationships. Such analysis also highlights important differences in China's engagement between subregions, individual states, and sectors, as well as commonalities across them. It thus calls attention to elements of China's strategy and style that transcend region, and factors that influence the PRC approach in both regions, including partner nation economic structure and governance, historic experience with China, and geographic strategic position. In short, such comparative analysis thus provides important insights both into patterns of China's global engagement, as well as promising ideas in the formulation of policy by the US and partners in both regions in response.

The present work examines patterns of PRC engagement across Europe, versus in Latin America, with attention to both commonalities in China's goals in each, how their pursuit and the associated results vary, and why.

\section{PRC GLOBAL OBJECTIVES, IMPERATIVES, AND ENGAGEMENT STYLE}

The PRC's overarching objectives for its global engagement is arguably the restoration of China as a civilizational power, wealthy, modern and strong, with the Chinese Communist Party in an unquestioned position of governance over that Chinese state. While achieving these goals has military, societal control, and political components, the focus of China's global strategy for doing so is principally economic: restructuring of the global order to support the PRC accumulation of wealth and associated power ${ }^{225}$. In doing so, China uses its StateOwned companies as a key instrument, positioning them to capture as much as possible of value added in economic activities from extracting commodities to selling high-end goods and services to building and operating the multidimensional infrastructure that connects the global economy.

The path the PRC has chosen to build its wealth within the interdependent world order, generates four imperatives: reliable access to commodities, foodstuffs to feed the 1.4 billion Chinese people, markets for Chinese goods and services (particularly in strategically valued sectors), and access to associated technologies.

The PRC engagement style in both Latin America and Europe, and elsewhere is marked by certain general characteristics. These include leveraging

\footnotetext{
224 Don Giolzetti, "China's Front Door to America's Backyard," The Diplomat, June 28, 2019, https://thediplomat.com/2019/06/chinas-front-door-to-americas-backyard/.

${ }^{225}$ See R. Evan Ellis, "Why China's Advance in Latin America Matters," National Defense, January 27, 2021, https://www.realcleardefense.com/2021/01/27/why_chinas_advance_in_latin_america_matters_658054.html.
} 
of the attractiveness of the large PRC market, its financial resources, and the appeal of Chinese companies as local partners. It also includes a significant role for the PRC government in coordinating large multi-sectoral deals that are more difficult for governments of free market economies. It includes using the Chinese government's domestic regulatory powers for implicit or explicit bargains to support the efforts of its companies in their negotiations abroad ${ }^{226}$.

At the firm level, similarities in the PRC approach to different regions are supported by the fact that the same PRC-headquartered SOEs, with imperatives and style stemming from those Chinese roots, are engaging in multiple parts of the world.

While the PRC government supports the advance of its state owned enterprises (SOEs) as the repository of wealth, commercial and technological capability in advancing the Chinese cause, it often "guides from behind", setting general policy direction, allowing its SOEs to take the initiative, then getting behind them, or making corrections, as it becomes apparent what works and what causes problems.

With respect to these SOEs and other Chinese businesses, PRC-based companies in both Europe and Latin America are advancing in their learning through participation as stakeholders "on the ground" where they operate, acquiring key capabilities through internal processes, partnerships, and strategic acquisitions where necessary. Sometimes the advance involves acquiring minority shares rather than a majority stake of a targeted firm, affording the opportunity to learn in a less politically exposed way before proceeding to majority ownership. In Latin America, this can be seen with acquisition by Chinese firms of minority stakes in firms such as Perenco ${ }^{227}, \mathrm{Galp}^{228}, \mathrm{CBMM}^{229}$ and $\mathrm{SQM}^{230}$.

Chinese companies are further evolving in how they engage, moving from buying companies with proven commodity reserves in sectors such as petroleum and mining, to merely extract resources, to participating in the riskier and more technically complex process of exploring and developing those fields. Similarly, PRC-based companies are transitioning from merely building physical infrastructure such as roads, railroads and bridges, to operating it often through Public-Private Partnership contracts. The latter implies a more intensive, longer-

\footnotetext{
${ }^{226}$ For a more detailed discussion, see R. Evan Ellis, "China’s Diplomatic and Political Approach in Latin America and the Caribbean," Testimony before the US-China Economic and Security Review Commission, May 20, 2021, https://www.uscc.gov/sites/default/files/2021-05/Evan_Ellis_Testimony.pdf.

227 Jeff Fick, "Perenco's Brazil Unit to Sell 10\% Stake in Offshore Blocks to Sinochem," The Wall Street Journal, January 8, 2012, https://www.wsj.com/articles/SB10001424052970204257504577148443070091790.

${ }^{228}$ Judy Hua, Wan Xu, and Ken Wills, "Sinopec signs \$3.5 billion deal for Galp's Brazil oil asset," Reuters, November 11, 2011, https://www.reuters.com/article/us-galp-brazil-sale/sinopec-signs-3-5-billion-deal-for-galpsbrazil-oil-asset-idUSTRE7AA0ZF20111111.

${ }^{229}$ Diana Kinch, "Chinese Steelmakers Buy Into Brazil's CBMM,” The Wall Street Journal, September 2, 2011, https://www.wsj.com/articles/SB10001424053111904583204576546890451706256.

${ }^{230}$ Antonio de la Jara, “Tianqi buys stake in lithium miner SQM from Nutrien for $\$ 4.1$ billion," Reuters, December 3, 2018, https://www.reuters.com/article/us-chile-tianqi-lithium-idUSKBN1O217F.
} 
term relationship with local governments, labor forces and communities, creating expanded opportunities for learning, influence, and conflict.

In general, as this work will show, the most significant variations in China's pattern of engagement are not between regions such as Europe versus Latin America, per se, but between parts of each region possessing different characteristics, such as factor endowments, markets, technological level and sophistication of local companies and historical legacies.

On one hand, in parts of both Latin America and Europe, particularly in Eastern and Central Europe, weaknesses in institutions and commitments to transparency, democracy and institutional processes, combined with urgent need for development assistance, has given the PRC and its companies important openings for business and political influence.

On the other hand, the negative historical legacy of domination by an external communist power which suppressed individual liberties freedom of discourse, has arguably made some Eastern European countries such as Romania more sensitive than their Latin American counterparts to PRC authoritarian practices at home and abroad. Compounding the effect of such sensitivity, the perceived security threat from Russia in much of Eastern and Central Europe has arguably made its government more open to aligning themselves with the US and its caution regarding the PRC, working through those governments' interest in leveraging the US and NATO in balancing the Russian threat.

\section{PRC ENGAGEMENT SEEKING COMMODITIES} AND FOODSTUFFS

In Latin America and the Caribbean Chinese companies have played an important role as purchasers of the region's petroleum, minerals and agricultural products ${ }^{231}$. Particularly after 2010 PRC-based companies expanded their position on the ground in the petroleum and mining sectors, including not only Venezuelan oil, but also expanded participation in the petroleum industry in Argentina, Brazil, Ecuador, Peru, Guyana, and Mexico, among others.

PRC Chinese mining participation includes purchases of Chilean copper and potassium nitrate, $\$ 15$ billion worth of mining investments in $\mathrm{Peru}^{232}$, mining investments in southern Ecuador, Argentina, Brazil, and bauxite mining in the Caribbean basin. In strategic minerals, it includes a significant Chinese presence in lithium, including Tianqi's 25\% share of the Sociedad Quimica y Minera (SQM) lithium operation in the north of Chile, Gangfeng's operation of the

\footnotetext{
${ }^{231}$ R. Evan Ellis, "Chinese Engagement in Latin America in the Context of Strategic Competition with the United States," Testimony to the U.S.-China Economic and Security Review Commission, June 24, 2020, https://www.uscc.gov/sites/default/files/2020-06/Ellis_Testimony.pdf.

${ }^{232}$ See, for example, R. Evan Ellis, "Peru's Multidimensional Challenge - Part 3: engagement with China," Global Americans, November 20, 2020, https://theglobalamericans.org/2020/11/perus-multidimensional-challenge-part3 -engagement-with-china/.
} 
Cauchari-Olaroz project in Argentina ${ }^{233}$, Gangfeng's assumption of majority control of the Bacanora mine in Mexico's Sonora desert ${ }^{234}$, and Xinjiang TBEA's activities in the Uyuni salt flats in the south of Bolivia ${ }^{235}$. Through a minority stake in the company Companhia Brasileira de Metalurgia e Mineração (CBMM), Chinese investors also have a role in the extraction of niobium in Brazil $^{236}$, one of the few locations outside the PRC where it is commercially viable.

In agriculture, the PRC is the largest export market for Brazilian soybeans and Argentine beef, and an increasingly important market for Ecuador's shrimp, and sugar from El Salvador and the Caribbean basin. Since 2014, PRC-owned companies Nidera and Noble have leveraged the purchasing power of parent company China National Cereals, Oils and Foodstuffs Corp (COFCO) to advance their position in the sector. PRC-based fishing companies are active in Peru, off both the Pacific and Atlantic coasts of South America, and are key users of ports in Uruguay. PRC-based forestry companies such as China Greenheart and Bai Shan Lin are active in the interior of Guyana and Suriname, and more recently, in Uruguay.

Within Europe, like Latin America, PRC interest in the region as a supplier of commodities and foodstuffs varies between more technologically developed Western European countries and he rest. On one hand, wealthy Chinese consumers have become a key source of demand for European brand-name luxury products. By contrast, newer EU entrants and Non-EU states generally sell the PRC far less, with a much greater focus on the export of lower value added goods. As examples, 94\% of Montenegro's exports to the PRC were mining products, as were $60 \%$ of North Macedonia's, and $70 \%$ of Bulgaria's. Serbia's exports to the PRC were dominated by agricultural products. Latvia's exports to China represent a mix of agricultural products and metals. In Eastern Europe, as in Latin America, there are exceptions to the pattern. Croatia exports transport vehicles to China,

\footnotetext{
${ }^{233}$ Dalilia Ouerghi, "China's Ganfeng completes majority stake acquisition in Argentina lithium project," Metals Bulletin, August 28, 2020, https://www.metalbulletin.com/Article/3948479/Chinas-Ganfeng-completes-majoritystake-acquisition-in-Argentina-lithium-project.html.

234 "Ganfeng Lithium increases stake in Bacanora's Sonora project to 50\%," Reuters, November 13, 2020, https://www.reuters.com/article/bacanora-lithium-ganfeng/ganfeng-lithium-increases-stake-in-bacanoras-sonoraproject-to-50-idUSL8N2HZ54S.

${ }^{235}$ Miriam Telma Jemio, "Bolivia rethinks how to industrialize its lithium amid political transition," Dialogo Chino,

May 19, 2020, https://dialogochino.net/en/extractive-industries/35423-bolivia-rethinks-how-to-industrialize-itslithium-amid-political-transition/.

${ }^{236}$ Jake Spring, "Hands off Brazil's niobium: Bolsonaro sees China as threat to utopian vision," Reuters, October 25, 2018, https://www.reuters.com/article/us-brazil-election-china-niobium/hands-off-brazils-niobium-bolsonarosees-china-as-threat-to-utopian-vision-idUSKCN1MZ1JN.
} 
while Romania exports industrial machinery, optical and medical apparatuses, electrical machinery, and vehicle parts and components ${ }^{237}$.

Beyond the issue of the composition of exports to China, the overall level of such exports to China from the less wealth countries of Europe are lower than their greater physical proximity to China (vis-à-vis Latin America) would predict ${ }^{238}$. Reflecting such dynamics, Eastern Europe's push for greater Chinese purchases of its agricultural goods becoming a particular theme at the February $202117+1$ summit $^{239}$.

In both Europe and Latin America, the PRC has used its considerable financial resources to buy interest in Western suppliers with key technologies and valued brands. With the brand name companies from Western Europe, however, the PRC hosts more stores within the PRC itself, as well as copying their brandname products. In other parts of Europe, however, as in Latin America, the focus of PRC investment is more on secure source of commodity supply. In Romania, for example, Chinese companies are acquiring local agricultural firms, particularly those involved with grains ${ }^{240}$.

\section{MARKETS}

In Latin America, the significant number of middle-income countries and populated urban centers have made it increasingly important as a market for Chinese goods, as PRC-based companies have diversified beyond selling to the US and the higher income countries of Western Europe and Asia ${ }^{241}$. Latin American states, like many Eastern European ones, are thus attractive to Chinese companies as a market for entry-level goods competing on the basis of price, including autos, consumer electronics, and household goods. This also includes cell phones and other telecommunication devices and consumer electronics, as well as clean energy technology, such as electric cars and buses, which the Chinese have sold from Chile to Brazil and Uruguay and beyond.

Western Europe, by contrast, has long been a market for PRC consumer goods as its companies incorporated new technologies and capabilities and moved up the value chain. Indeed, a study by the Hungary-based think tank CEECAS estimates that within Europe, the nations of the EU have received the greatest portion of Chinese investment, driven by the attractiveness of their markets and

\footnotetext{
237 "Empty Shell No More: China's Growing Footprint In Central and Eastern Europe," China Observers in Central and Eastern Europe (CHOICE), Ivana Karásková, Ed., April 2020, https://chinaobservers.eu/new-publicationempty-shell-no-more-chinas-growing-footprint-in-central-and-eastern-europe/.

238 "Empty Shell No More," 2020.

239 Stuart Lau, "China's Eastern Europe strategy gets the cold shoulder," Politico, February 9, 2021, https://www.politico.eu/article/china-xi-jinping-eastern-europe-trade-agriculture-strategy-gets-the-coldshoulder/.

240 "Chinese investment fund expands into Romanian agriculture," Romania Insider, September 27, 2019, https://www.romania-insider.com/chinese-fund-romanian-agriculture.

${ }^{241}$ Ellis, "Chinese Engagement in Latin America..." 2020.
} 
technologies. ${ }^{242}$ For Western Europe, however, such investments have been blocked, to a degree, by government strategic investment screening mechanisms. The non-EU states of Eastern Europe, on the other hand, arguably resemble Latin America with respect to China's interest in their potential as middle income markets, open to products competing on price.

\section{INFRASTRUCTURE ORIENTATION}

In Latin America, the PRC orientation toward "connectivity" as a central tool for its advance can be seen in the 19 countries from the region that have joined the Belt and Road project since it was extended to the Western hemisphere with Panama's membership in 2018. Within that focus on connectivity, however, Chinese companies have evolved from building roads, railroads and other land infrastructure (often through loans to politically sympathetic populist governments), to pursuing contracts in more advanced, strongly institutionalized countries such as Colombia and Chile, often through vehicles such as public private partnerships that allow Chinese companies to capitalize on their financial contributions to the project, although correspondingly increasing their level of project risk. $^{243}$

In recent years the PRC has won important public-private partnership (PPP) projects in Colombia such as the highway from Medellin to the Gulf of Uraba, and more recently, the $\$ 4.5$ billion Bogota metro. ${ }^{244}$ In Chile, in April 2021, a Chinese company was awarded a PPP contract to upgrade a segment of Chile's important Highway 5 from Talca to Chillin. ${ }^{245}$

In the port sector Chinese activities in Latin America include six Hutcherson Port operations in Mexico, three in the Bahamas, three in Panama, and one in Argentina. ${ }^{246}$ China Merchant port owns the Port of Kingston Jamaica. ${ }^{247}$ In Ecuador, PRC-based China Harbour is subcontracted to port operator DP World to build the port of Posorja, ${ }^{248}$ intended as the country's new commercial gateway to the Pacific. PRC-based companies are involved in the operation and expansion of four major Brazilian ports, including a major

\footnotetext{
${ }^{242}$ Tamás Matura, "Chinese Investment in Central and Eastern Europe: A reality check," CEECAS, April 21, 2021, https://www.china-cee-investment.org/.

${ }^{243}$ Ellis, "Chinese Engagement in Latin America..." 2020.

${ }^{244}$ Jorge Valencia, "By building Bogotá metro, China makes a new breakthrough in Latin America," PRI, November 5, 2020, https://www.pri.org/stories/2020-11-05/building-bogot-metro-china-makes-new-break through-latin-america.

${ }^{245}$ David Arminas, "Chile awards CRCC major Talca-Chillán upgrade," World Highways, April 14, 2021, https://www.worldhighways.com/wh12/news/chile-awards-crcc-major-talca-chillan-upgrade.

${ }^{246}$ Hutchinson Ports, Official Website, Accessed June 3, 2021, https://hutchisonports.com/ports/americas/.

247 "Chinese firm takes over Kingston Freeport management company," Stabroek News, April 25, 2020, https://www.stabroeknews.com/2020/04/25/news/regional/jamaica/chinese-firm-takes-over-kingston-freeportmanagement-company/.

${ }^{248}$ Michele Labrut, "DP World launches construction of deepwater port in Posorja, Ecuador," Seatrade Maritime News, September 28, 2017, https://www.seatrade-maritime.com/americas/dp-world-launches-constructiondeepwater-port-posorja-ecuador.
} 
multimodal agricultural port project in the port of São Luis. ${ }^{249}$ China Minmetals is similarly leading a Chinese consortium to build the $\$ 3$ billion Chancay minerals port or Peru's Pacific coast. ${ }^{250}$ Chinese consortiums have further proposed major multimodal ports and free trade zone facilities in El Salvador, and in Manzanillo, in the Dominican Republic.

With respect to riverine infrastructure, the China Communications Construction Company (CCCC) subsidiary China Harbour is dredging an important river route in the Peruvian amazon, while CCCC subsidiary Shanghai Dredging is deepening a strategic corridor of the Paraguay and Parana River ${ }^{251}$ which serves as the riverine access point for five South American countries, even while it works other dredging contracts across the same river in neighboring Uruguay.

In the electricity sector, PRC-based companies have made significant advances in generation, transmission and distribution infrastructure across the region. In generation, they have worked a large number of projects in the renewables area. Among these are building and supplying components and financing for wind and solar farms, including Latin America's biggest photovoltaic complex, Cauchari, in the North of Argentina, ${ }^{252}$ and a proposed new 1.1-gigawatt facility in Açu, Brazil ${ }^{253}$. Chinese firms have also built numerous hydroelectric facilities in the region, including six projects in Ecuador, three Bolivia, two in Argentina ${ }^{254}$, two in Peru ${ }^{255}$, and two attempts in Honduras. China National Nuclear Corporation is also building its Hualong-1 nuclear reactor in Argentina's Atucha complex ${ }^{256}$, and is interested in building a reactor in Brazil's Angra facility.

With respect to transmission, Chinese firms have particularly focused on high-voltage long-distance lines, with Chinese firms installing transmission

\footnotetext{
${ }^{249}$ Marcela Ayres, "China to announce billion-dollar investment in Brazilian port of Sao Luis: sources," Reuters, November 13, 2019, https://www.reuters.com/article/us-brazil-brics-china-investment/china-to-announce-billiondollar-investment-in-brazilian-port-of-sao-luis-sources-idUSKBN1XN2NM.

250 "Cosco sees 2020 construction start for US\$3bn Chancay port," BNAmericas, June 26, 2019, https://www.bnamericas.com/en/news/cosco-sees-2020-construction-start-for-us3bn-chancay-port.

251 "China competes in the dredging of Paraguay/Parana Waterway which handles 90 million tons of grains," Mercopress, November 25, 2020, https://en.mercopress.com/2020/11/25/china-competes-in-the-dredging-ofparaguay-parana-waterway-which-handles-90-million-tons-of-

grains\#: :text=A\%20Chinese\%20company\%20entered\%20the,river\%20course\%20beginning\%20in\%202021.

${ }^{251}$ Ellis, "China's Bid to Dominate Electrical Connectivity in the Americas," 2021.

${ }^{252}$ Luis Colqui, "Jujuy. Cauchari: el parque solar más grande de América Latina comenzó a vender energía al país," La Nacion, September 26, 2020, https://www.lanacion.com.ar/economia/jujuy-cauchari-parque-solar-masgrande-america-nid2461924/

253 "Chinese duo to build 1.1-GW solar power plant in Brazil," Renewables Now, April 29, 2021, https://renewablesnow.com/news/chinese-duo-to-build-11-gw-solar-power-plant-in-brazil-739550/.

${ }^{254}$ R. Evan Ellis, "New Directions in the Deepening of China-Argentine Engagement," Global Americans, February 11, 2021, https://theglobalamericans.org/2021/02/new-directions-in-the-deepening-chinese-argentineengagement/.

255 "China's SGCC offers to construct HidroAysen power line," Global Transmission Report, January 4, 2012, https://www.globaltransmission.info/archive.php?id=10056.

${ }^{256}$ Sofia Diamante, "La energía nuclear, una herencia a resolver con China," La Nacion, January 22, 2020, https://www.lanacion.com.ar/economia/la-energia-nuclear-una-herencia-a-resolver-con-china-nid2326138/.
} 
infrastructure from connecting the Belo Monte hydroelectric facility to the south of Brazil, to a \$191 million high-voltage connection completing Uruguay's power distribution ring ${ }^{257}$. Since 2010, Chinese firms have invested tens of billions of dollars to buy electricity transmission assets in Brazil ${ }^{258}$. In Peru, through Yangtze Power's 2019 \$3.6 billion acquisition of Luz del Sur ${ }^{259}$, PRC-based firms have acquired approximately half of the energy infrastructure of the greater Lima area. Most recently, through five successive acquisitions in Chile (Transelec, Atiaia, Pacific Hydro, Chilquinta, and State Grid's purchase of Compañía General de Electricidad (CGE) from Spain's Naturgy) ${ }^{260}$, PRC-based companies have obtained control over $57 \%$ of Chile's entire power grid ${ }^{261}$.

In the telecommunications sector in Latin America, the PRC-based companies Huawei and ZTE have become major suppliers to Latin America's commercial providers and government entities, and are positioned to play a significant role in $5 \mathrm{G}^{262}$. China's position is important not only as a strategic, highvalue added technology and a source of leverage as a type of infrastructure, but also because, pursuant to the PRC 2017 National Security Law, the PRC government has delegated itself the authority to confiscate data of Latin American or other global users to advance its commercial and other strategic interests.

During the Covid-19 pandemic, the PRC overcame obstacles placed against the inclusion of Huawei in 5G auctions by Brazil and the Dominican Republic, among others, through linking expedited access to Covid-19 vaccines to those countries' abandonment of commitments to exclude Huawei from their $5 \mathrm{G}$ networks.

In e-commerce, the Chinese rideshare company DiDi Chuxung is active in multiple countries across the region, including Brazil, Columbia, Chile, Panama, the Dominican Republic, and Argentina, among others. For a modest investment, the company provides employment to thousands across the region as drivers, while also collecting sensitive data on them, and the travel of their passengers.

In a similar fashion, the Chinese company Alibaba is a growing competitor to Amazon, MercadoLibre and other firms for the dominance of Ecommerce and

\footnotetext{
257 "UTE firmó contrato para el cierre del anillo de transmisión del norte, obra clave en el período," El Pais, May 31, 2021, https://negocios.elpais.com.uy/ute-firmo-contrato-cierre-anillo-transmision-norte-obra-claveperiodo.html

${ }^{258}$ R. Evan Ellis, "China's Bid to Dominate Electrical Connectivity in Latin America," China Brief, Vol. 21, Issue 10, May 21, 2021, https://jamestown.org/program/chinas-bid-to-dominate-electrical-connectivity-in-latinamerica/.

259 "China Yangtze Power completed its acquisition of Peruvian power company, Luz Del Sur," BN Americas, April 24, 2020, https://www.bnamericas.com/en/news/china-yangtze-power-completed-its-acquisition-ofperuvian-power-company-luz-del-sur.

260 "Regulador chileno aprueba sin condiciones compra de eléctrica CGE por china State Grid," Reuters, March 31, 2021, https://www.infobae.com/america/agencias/2021/03/31/regulador-chileno-aprueba-sin-condicionescompra-de-electrica-cge-por-china-state-grid-2/.

${ }^{261}$ Ellis, "China's Bid to Dominate Electrical Connectivity in the Americas," 2021.

262 "Brazil's Bolsonaro to allow China's Huawei in 5G auctions: newspaper," Reuters, January 16, 2021, https://www.reuters.com/article/us-brazil-huawei-tech-idUSKBN29L0JM.
} 
the supply of consumer demand in Latin America and elsewhere, including doorto-door delivery in the region.

Turning to Europe, the location of the region as the original Western anchor of China's Belt and Road Initiative has made China's focus on connectivity in the region even more directly relevant than that in more distant Latin America.

In Europe, as with its pursuit of other markets, the PRC has arguably had more success in winning infrastructure projects in the less strongly institutionalized countries principally outside the EU. With the help of acquisitions, despite increasing concern and pushback from the EU, China has advanced across the region. Signature cases include the acquisition of the Greek port of Piraeus by PRC-based shipping company COSCO, followed by efforts to transform it into the biggest port in Europe ${ }^{263}$. Indeed, the PRC now has a presence in 13 ports in the region ${ }^{264}$ including the key European maritime hub of Rotterdam $^{265}$.

In Europe, as in Latin America, only a small fraction of announced PRC infrastructure projects proposed have actually gone forward. Indeed, the European think tank MERICS estimates that only \$715 million in Chinese projects have been completed in the region to date, with $\$ 3$ billion more in projects in progress ${ }^{266}$. Among the major infrastructure projects announced, there has been a significant variation in which countries have received them. They have generally gone more toward populist regimes, with Hungary receiving \$3.6 billion in Chinese projects in 2020, while others such as Latvia have received almost none. $^{267}$

With respect to the specifics of project financing, while China has "bought into" the EU through acquisitions, its loan-based projects tied to the use of Chinese companies and workers have gone to populist regimes outside the EU who, like leftist populists and smaller states in Latin America, do not have better options. ${ }^{268}$ Indeed, as in Latin America, China has set up an "investment fund" in addition to the Belt and Road's Asia Infrastructure Investment Bank (AIIB) for

\footnotetext{
${ }^{263}$ Silvia Amaro, "China bought most of Greece's main port and now it wants to make it the biggest in Europe," CNBC, November 15, 2019, https://www.cnbc.com/2019/11/15/china-wants-to-turn-greece-piraeus-port-intoeurope-biggest.html.

${ }^{264}$ Joanna Kakissis, "Chinese Firms Now Hold Stakes In Over A Dozen European Ports," NPR, October 9, 2018, https://www.npr.org/2018/10/09/642587456/chinese-firms-now-hold-stakes-in-over-a-dozen-european-ports.

${ }^{265}$ "China is making substantial investment in ports and pipelines worldwide," The Economist, February 6, 2020, https://www.economist.com/special-report/2020/02/06/china-is-making-substantial-investment-in-ports-andpipelines-worldwide.

266 "Belt and Road reality check: How to assess China's investment in Eastern Europe," MERICS, July 10, 2019, https://merics.org/en/analysis/belt-and-road-reality-check-how-assess-chinas-investment-eastern-europe.

267 "Eastern Europe ends love fest with China amid Beijing-EU rift," Nikkei Asia, May 28, 2021, https://asia.nikkei.com/Politics/International-relations/Eastern-Europe-ends-love-fest-with-China-amid-BeijingEU-rift.

${ }^{268}$ Tomasz Bieliński, Magdalena Markiewicz, and Ewa Oziewicz, "Do Central and Eastern Europe Countries Play a Role in the Belt and Road Initiative? The Case of Chinese OFDI into the CEE-16," Comparative Economic Research, Central and Eastern Europe, Volume 22, Number 2, 2019, http://doi.org/10.2478/cer-2019-0009.
} 
the nations of Eastern Europe to turn to Chinese companies for their projects. ${ }^{269}$ The Eastern Europe-based think tank CEECAS estimates that $75-85 \%$ of projects are financed by Chinese loans, and such loans may reach $8 \%$ of the GDP in Montenegro, $12 \%$ in Serbia, $10 \%$ in Bosnia-Herzegovina and $7 \%$ in NorthMacedonia. ${ }^{270}$

Such financing has also become increasingly problematic for the countries incurring it. Montenegro, for example, is facing serious fiscal constraints due in part to an expensive loan-financed contract for an economically questionable road connecting its coast at Bar to neighboring Serbia. ${ }^{271}$ As seen in Latin America, but for different reasons, the Montenegrin government is reportedly now considering turning to a PPP contract structure to complete the project, which would, in turn, give the PRC a more extended presence in the country as operator of the critical infrastructure as a toll road. ${ }^{272}$

Eastern European countries have also increasingly began pushing back on PRC participation in major infrastructure projects. Romania, for example, chose to exclude Chinese companies from participation in key physical infrastructure projects over a lack of EU-style credentials indicating their ability to successfully perform the project work. ${ }^{273}$

In the electricity sector, in Europe like Latin America, Chinese companies are actively pursuing wind and solar ${ }^{274}$ generation and transmission projects. ${ }^{275} \mathrm{In}$ Europe, by contrast to Latin America, however, nuclear power plays a far greater role, with projects being actively pursued by the Chinese. Nonetheless, in nuclear energy, Eastern European countries have begun to push back. In January 2021, Czechia excluded China National Nuclear Corporation (CNNC) from a nuclear reactor project. ${ }^{276}$ Romania similarly reversed a prior decision to contract CNNC for $\$ 8$ billion $^{277}$ to build two nuclear reactors at its Cernavodă ${ }^{278}$, after a European consortium had pulled out. ${ }^{279}$

With respect to telecom infrastructure, while PRC companies Huawei and ZTE have an important role across the region, their role in $5 \mathrm{G}$ across Europe has

\footnotetext{
269 "China-Central and Eastern Europe Investment Cooperation Fund, Official Website, Accessed June 3, 2021, http://china-ceefund.com/.

${ }^{270}$ Matura, 2021.

${ }^{271}$ Noah Barkin and Aleksandar Vasovic, "Chinese 'highway to nowhere' haunts Montenegro," Reuters, July 16, 2018, https://www.reuters.com/article/us-china-silkroad-europe-montenegro-insi-idUSKBN1K60QX.

272 Barkin and Vasovic, 2018.

273 "Romania reveals the limits of China's reach in Europe," Politico, May 3, 2021, https://www.politico.eu/article/romania-recoils-from-china-aggressive-diplomacy/.

${ }^{274}$ See, for example, "Chinese Solar Company Expanding to Eastern Europe," Eastern Europe Business News, February 16, 2018, http://www.eebusiness.net/chinese-solar-company-expanding-to-eastern-europe.

275 "China-Central and Eastern Europe Investment Cooperation Fund, 2021.

${ }^{276}$ Robert Muller, "China sidelined for Czech nuclear tender, Russia still in play," Reuters, January 27, 2021, https://www.reuters.com/world/china/china-sidelined-czech-nuclear-tender-russia-still-play-2021-01-27/.

277 Andreea Brînză, "How the US-China Competition Is Playing out in Romania," The Diplomat, November 1, 2019, https://thediplomat.com/2019/11/how-the-us-china-competition-is-playing-out-in-romania/.

278 "Romania reveals the limits of China's reach in Europe," 2021.

${ }^{279}$ Brînză, 2019.
} 
been mixed, with Great Britain temporarily seeking to exclude Huawei from its $5 \mathrm{G}$ rollout, prompting the PRC to defund major British infrastructure projects there. ${ }^{280}$ Most Eastern European countries as well have signed onto Washington's "Clean Networks" initiative, excluding Chinese companies such as Huawei from $5 \mathrm{G} .{ }^{281}$ Romania was one of the countries to exclude Huawei from its networks, including $5 \mathrm{G}$, over security concerns. ${ }^{282}$

\section{MILITARY ENGAGEMENT}

In the military realm, PRC engagement with Latin America is arguably both more cautious, and more extensive than its engagement with Europe.

In Latin America, Chinese arms companies such as NORINCO have leveraged political alignment with anti-US populist governments such as Venezuela, Bolivia, Argentina, and (previously) Ecuador to sell a significant quantity of military end items to the region. ${ }^{283}$ These have included providing radars, K-8 fighters, and Y-8 and Y-12 small military transport aircraft to Venezuela, radars, military trucks and assault rifles to Ecuador, K-8 fighters, Z-9 helicopters, and armored vehicles to Bolivia, and armored vehicles to Argentina. ${ }^{284}$ Currently, the PRC is further in talks with Argentina to sell that populist regime its FC-1 fighter, which would be the most sophisticated Chinese military end item sold in the region to date. ${ }^{285}$

Beyond Latin America's populist leftist regimes, the PRC has also sold a more limited quantity of military goods to other countries in the region. These include providing an offshore patrol vessel (OPV) to Trinidad and Tobago, ${ }^{286}$ and a truck-mounted multiple launch rocket system to Peru. ${ }^{287}$ In order to build its goodwill and market position, the PRC has also regularly donated, rather than selling, limited quantities of military trucks, construction equipment, police cars, motorcycles and other equipment to a broad range of other security forces in the region. ${ }^{288}$

\footnotetext{
${ }^{280}$ Hadas Gold, "UK bans Huawei from its 5G network in rapid about-face," CNN, July 14, 2020, https://www.cnn.com/2020/07/14/tech/huawei-uk-ban/index.html.

${ }^{281}$ Andreea Brînză, "How China's 17+1 Became a Zombie Mechanism," The Diplomat, February 10, 2021, https://thediplomat.com/2021/02/how-chinas-171-became-a-zombie-mechanism/.

282 "Romania reveals the limits of China's reach in Europe," 2021.

${ }^{283}$ For a detailed discussion of such sales and other relationships, see R. Evan Ellis, "Chinese Security Engagement in Latin America," Center for Strategic and International Studies, November 2020, https://www.csis.org/analysis/chinese-security-engagement-latin-america. See also Ellis, "The Evolution of Chinese Security Engagement in Latin America," 2021.

284 Allan Nixon, "China's Growing Arms Sales to Latin America," The Diplomat, August 24, 2016, https://thediplomat.com/2016/08/chinas-growing-arms-sales-to-latin-america/.

${ }^{285}$ Ellis, "New Directions in the Deepening of China-Argentine Engagement," 2021.

286 "Chinese vessel coming to Trinidad," Jamaica Observer, February 25, 2014, https://www.jamaicaobserver.com/news/Chinese-vessel-coming-to-Trinidad.

287 "Peru selecciona el sistema táctico de lanzacohetes múltiples Norinco tipo 90B," Infodefensa, October 1, 2014, https://www.infodefensa.com/latam/2014/01/10/noticia-selecciona-sistema-tactico-lanzacohetes-multiplesnorinco.html.

${ }^{288}$ Ellis, "Chinese Security Engagement...”, 2020.
} 
The states of Western Europe, with their own highly regulated and protected arms industries, and with their associations with the North Atlantic Treaty Organization (NATO), generally have not bought Chinese equipment, although several populist Eastern European countries have, to some degree, paralleled the Latin American experience through purchasing limited quantities of equipment from the PRC and accepting some donations for their security forces. In 2020, for example, Serbia purchased 6 CH-92A Chinese combat drones and an unspecified number of Chinese FK-3 surface to air missiles ${ }^{289}$, as well as receiving Covid-19 related military donations. ${ }^{290}$

Beyond equipment, in Latin America, virtually all of the region's militaries have sent personnel to training and professional military education courses in the PRC, including short courses at its National Defense University in Beijing, and longer Command and General Staff courses at its Army and Navy mid-level military schools in and outside Nanjing. Similarly, Latin American PME and other institutions at all levels have sent delegations to the PRC for professional exchanges, and some Latin American institutions have hosted and trained small numbers of Chinese People's Liberation Army (PLA) personnel. These include close US ally Colombia, which hosted PLA personnel in its Lanceros special forces course in Tolemaida. ${ }^{291}$ It also includes Brazil, which hosted PLA members at its respected jungle warfare school $^{292}$ as well as at its peacekeeping institute, CCOPAB.

Beyond training, education and institutional visits, the PRC has also sent its military ships to the region for port calls, including three separate missions by its hospital ship "Peace Arc" to the region (in 2011, 2015 and 2018-2019), sent PLA peacekeeping forces to Haiti from 2004 through 2012, and has conducted limited military exercises in the region with Chile and Peru, among other activities. ${ }^{293}$ China has notably not, to date, sought to establish anti-US military alliances in the region, or military bases as it has done in Djibouti, in Africa. Its restraint in Latin America likely reflects PRC deference of the proximity of Latin America to the United States, and the desire to avoid both the provocative effect and expense of a base that the People's Liberation Army (PLA) is not yet in a position to use.

In Europe, Non-EU states in Europe, and to a lesser extent, those of the EU, have followed the Latin American pattern in sending personnel to Chinese

\footnotetext{
289 "Serbian purchase of missile defence system shows ties deepening with China," Reuters, August 3, 2020, https://www.reuters.com/article/us-serbia-arms-china-idUSKBN24Z171.

290 Aljosa Milenkovic, "China and Serbia strengthening military ties," CGTN, March 27, 2021, https://newseu.cgtn.com/news/2021-03-27/China-and-Serbia-strengthening-military-ties-

YYwwasXdCM/index.html.

291 "Integrantes del Ejército Chino se entrenan en Colombia como Tiradores de Alta Precisión," FuerzasMilitares, October 23, 2016, http://www.fuerzasmilitares.org/notas/colombia/ejercito-nacional/7145-tap-50.html.

${ }^{292}$ Eben Blake, "Chinese Military Seeks Jungle Warfare Training From Brazil,"

International Business Times, August 10, 2015, https://www.ibtimes.com/chinesemilitary-seeks-jungle-warfaretraining-brazil-2046473.

${ }^{293}$ Ellis, "Chinese Security Engagement...”, 2020.
} 
schools, and conducted institutional visits, although the EU has arguably placed more emphasis on the later. Serbia, among others, has agreed to send its personnel to programs in the PRC, and to work with it to set up a school of traditional Chinese medicine within the Serbian Armed Forces. ${ }^{294}$

As in Latin America, and as with arms sales, China-Eastern Europe military institutional cooperation and visits has arguably been more extensive with more populist regimes, such as that of Viktor Orban in Hungary, which in March 2021, hosted China's Defense Minister Wei Fenghe to strengthen bilateral military ties. ${ }^{295}$

As in Latin America, the PLA has not sought to establish a base in or near Europe, likely for the same reasons. As with the US in Latin America, the PRC wishes to avoid the provocative effect that establishing a base in the region would have on its business partners, as well as the expense of a facility that the PRC is not yet in a position to use.

\section{POLITICAL ENGAGEMENT AND SOFT POWER}

In Latin America, the PRC has arguably used political engagement to support its economic objectives. Although leftist populist regimes such as Venezuela, Ecuador, Bolivia and Argentina have generally been more receptive than others to PRC government-to-government proposals, security cooperation and other sensitive areas, the PRC has been careful not to develop alliances with those nations that could be perceived a threatening to the West.

Across Latin America, as elsewhere, the PRC has used the lure of access to its markets and the attractiveness of partnering with PRC-based firms, to induce governments and businesses to censor themselves in order to avoid undercutting loans and investment from and business with Chinese companies. ${ }^{296}$

China's people to people diplomacy have also influenced its position with political and economic elites, and populations in Latin America. The PRC's 39 Confucius Institutes and 18 Confucius Classrooms in the region have arguably become centers of recruitment for identifying future Latin American leaders with a strong interest in China studies and an aptitude for learning the difficult Mandarin Chinese language and the Chinese character set. Through the Hanban relationship with the Confucius Institutes, thus, the PRC government offers the most promising of the region's Asia-facing young scholars the opportunity for language and university study in the PRC. They return, inherently grateful to the Chinese government for its role in enabling their careers, and assume come to

\footnotetext{
${ }^{294}$ Milenkovic, "China and Serbia strengthening military ties," 2021.

295 "China, Hungary to strengthen military cooperation," CGTN, March 25, 2021, https://newseu.cgtn.com/news/2021-03-25/China-s-Defense-Minister-visits-Budapest-for-official-talksYU5IRPv8NG/index.html.

${ }^{296}$ See, for example, R. Evan Ellis, "The Evolution of Chinese Soft Power in Latin America," in Soft Power with Chinese Characteristics, Kingsley Edney, Stan Rosen, and Ying Zhu, Eds. (Milton Park, England: Routledge, 2020).
} 
dominate the limited number of positions in China-facing parts of their government's bureaucracies, or the local business elite, or the scholarly community with sufficient knowledge to speak with authority and shape the discourse about the PRC in their countries.

Beyond Confucius Institutes and academic programs, the PRC uses the International Liaison Department (ILD) of the Chinese Communist Party to bring Latin American political party and other government representatives to China on goodwill-building missions. Other quasi-governmental affiliated organizations bring journalists, and think tank personnel to the PRC. While such trips may not convert the recipients of such generosity into pro PRC propagandists, it does subtly pressure them to self-censure their more critical comments about the PRC and its system, or at least to refrain from actively working to resist PRC activities in the Americas, lest the comments or activities of such Latin Americans offend the Chinese government and businesses, and thus undermine the ongoing access or other benefits from the PRC which is important to those invited, for their ongoing career success.

Beyond trips, the PRC often purchases advertising supplements in Latin American media, such as in the Chilean newspaper La Tercera ${ }^{297}$ Chinese media often also provides state-produced video feeds free of cost to television and internet news services in the region, which are too often accepted uncritically by regional news services not as PRC-crafted propaganda, but as objective news, shaping the way in which the PRC and its leaders are presented in images.

The collective impact of self-censorship by hundreds key individuals and institutions across the region, combined with the distortion of news coverage over the long run is to undermine Latin America's ability to clearly define and effectively mobilize against objectionable PRC behaviors, or to position the region to bargain effectively with the PRC to secure the country or region's own best interests from that engagement.

Such truncation of debate also extends to expression of disapproval by Latin American governments and elites over PRC actions in its own territory, or in its Asian neighborhood more broadly, including PRC repression of Uighurs in Xinjian, elimination of self-rule and repression of democracy in Hong Kong, or PRC construction and militarization of artificial islands in the South and East China Seas.

Latin America's seeming readiness to avoid speaking ill of the PRC when business with China or other benefits are potentially at stake, arguably reflects the region's historic detachment from the activities of states in other parts of the world that did not directly affect the region.

Turning to Europe, in its own bilateral political engagement with the PRC, the region parallels Latin America in its broad range of orientations toward the

297 R. Evan Ellis, "Chinese Advances in Chile," Global Americans, March 2, 2021, https://theglobal americans.org/2021/03/chinese-advances-in-chile/. 
PRC, both within and beyond the EU. Leaders such as Serbia's Aleksander Vucic and Hungary's Viktor Orban have paralleled Latin American populists such as Hugo Chavez or Evo Morales in their relative embrace of China. ${ }^{298}$ Nor is such receptivity to the PRC exclusively a characteristic of non-EU states. Within the EU, Greece has shown a particularly positive orientation toward the PRC, joining the Belt and Road Initiative in 2019. ${ }^{299}$ Czechia's Miloš Zeman has also showed a very positive orientation toward China, as has Germany's Angela Merkel, who has visited the PRC 12 times since 2005, in the context of numerous major German companies focused on the China market, possessing Chinese stakeholders, or both. ${ }^{300}$

In general, the nature of PRC influence in non-Western Europe resembles that of Latin America, driven by hopes for Chinese loans, investment projects, or hooking up with a Chinese partner for to do business in the region. The EU, however, specifically contrasts with Latin America in that their Chinese influence is arguably more influenced by access to the Chinese market, and Chinese stakeholders in European companies. Nonetheless, the effect of PRC limitation of discourse is the same.

Another contrast between the two regions, in the specifics of the lure of China, is the role of tourism as an economic attractor. For Europe, particularly in the less wealthy states of Central and Eastern Europe, the potential importance of attracting Chinese tourists is arguably greater than Latin America, particularly given the relatively smaller distances between China and the region. Currently, in addition to the customary European tourist destinations attractive to China of the United Kingdom, France, and Germany, Chinese are increasingly traveling to Croatia, Estonia and Hungary, among other destinations. ${ }^{301}$

In educational affairs, Central and Eastern Europe parallel Latin America with a modest number of Confucius Institutes which play an important role in recruiting the region's youth for studies in China through Hanban scholarships. Approximately 250 persons from each of the Baltic states, for example, are estimated to have been brought to the PRC on such scholarships in recent years. ${ }^{302}$

As with Latin America, the relative limited funding for China studies programs in Central and Eastern Europe create the risk that China-funded programs and China-trained scholars dominate the discourse in these countries regarding the nature of China. ${ }^{303}$

\footnotetext{
${ }^{298}$ David Hutt and Richard Q. Turcsányi, "No, China Has Not Bought Central and Eastern Europe,” Foreign Policy, May 27, 2020, https://foreignpolicy.com/2020/05/27/china-has-not-bought-central-eastern-europe/.

299 "Greece 'Appreciates' Joining China's Belt and Road Initiative," TeleSur, May 16, 2019, https://www.telesurenglish.net/news/Greece-Appreciates-Joining-Chinas-Belt-and-Road-Initiative-201905150022.html\#: : :text=The $\% 20 \mathrm{Greek} \% 20$ economy $\% 20$ has\%20benefited\%20from\%20joining\%20China\%E2\%80\% 99 s,the $\% 20$ few $\% 20 \mathrm{EU} \% 20$ countries\%20to\%20join\%20the \%20movement

${ }^{300}$ Hutt and Turcsányi, 2020.

301 "Empty Shell No More," 2020.

302 "Empty Shell No More," 2020.

303 "Empty Shell No More," 2020.
} 
Europe lists 132 Confucius Institutes, more than three times as many as Latin America, although these are disproportionately in Western Europe. In general, like Latin America, most Central and Eastern European States have one or two Confucius Institutes. China-friendly Hungary has five, although Belarus has six, but China-friendly Serbia has only two. ${ }^{304}$ There is a regional Confucius Center in Hungary ${ }^{305}$, paralleling the one for South America in Chile.

Within Europe, Western European countries generally have many more Institutes per country, including Spain with eight, Italy with 12, Germany with 19, and the United Kingdom with $30 .{ }^{306}$ Nonetheless, in recent years, attitudes toward Confucius Institutes and their activities in Western European countries has become more critical.

As with Latin America, beyond Confucius Institutes, China's People-topeople engagement with Europe includes outreach to political leaders and think tank professionals, including Chinese Communist Party International Liaison Department programs such as "Bridge for the Future" and the "China-CEEC Young Political Leaders' Forum. ${ }^{307}$

With respect to Chinese media influence in Europe, as in Latin America, the PRC invites reporters (principally from non-Western European countries) to the PRC for educational trips. Such as transporting Baltic State reporters to Tibet. As in Latin America, the Chinese in Europe also purchase advertising supplements in local media, with one example being the centrist Polish paper Rzeczpospolita. As in Latin America, but in a bolder fashion, the PRC has even purchased media outlets themselves, as seen in Czechia. ${ }^{308}$

By contrast to Latin America, Western Europe's protectionism, pride in its own historical legacy, and the strength of its environmental and human rights interests has arguably caused it to take a more aggressive stance regarding PRC activities, including the recent suspension of the China EU free trade deal over Chinese activities in Xinjian. ${ }^{309}$

As part of Europe's unique historically legacy, particularly among the nations of the East, concern over the influence of Russia (a factor largely absent in Latin America), incentivizes individual states to seek close relationships with the US, distancing themselves from engagement with the PRC that Washington might find of concern. ${ }^{310}$

\footnotetext{
304 "Confucius Institutes Around the World," Dig Mandarin, Accessed June 3, 2021, https://www.digmandarin.com/confucius-institutes-around-the-world.html

305 "Central and Eastern European Regional Center of Confucius Institute," Official Website, Accessed June 3, 2021, http://confucius-institutes.eu/index.php?r=site/about.

306 "Confucius Institutes Around the World," 2021.

307 "Empty Shell No More," 2020.

308 "Empty Shell No More," 2020.

309 "Eastern Europe ends love fest with China amid Beijing-EU rift," 2021.

310 Brînză, 2021.
} 


\section{MULTILATERAL ENGAGEMENT}

In multilateral diplomacy, the PRC plays an active role in a range of Latin America-facing institutions, including the United Nations Economic Commission on Latin America and the Caribbean (ECLAC) and the Inter-American Development Bank (IADB). Effectively, China works to ensure that the intellectual products of these institutions are not critical of PRC interests, and where possible, seeks projects within the organizations such as joint loan funds with the IADB in support of PRC agendas. ${ }^{311}$ Indeed, in May 2021, the head of the IADB, Mauricio Claver Carone, expressed concern regarding PRC exercise of influence within the institution. ${ }^{312}$

With respect to regional political bodies, China's tool of choice has been the Community of Latin American and Caribbean States (CELAC). Although the PRC has been an observer in the Organization of American States (OAS) since 2004, it has preferred to make CELAC its primary multilateral instrument for engagement with the region, as it has done with FOCAC in Africa and the 17+1 forum in Europe. For China, a key benefit of CELAC is that it lacks standing institutions, making it easier for the PRC to broadcast its agenda through the body, rather than having to negotiate with an entity more able to advance a collective Latin American position.

By comparison to Chinese engagement in Latin America, the European Union brings an inherent level of coordination as a multinational entity in facing the PRC. Arguably for this reason, paralleling Latin America, since 2012, the PRC has tried to use the $16+1$ mechanism (expanded with Greece 17+1), with its CELAC-like lack of permanent institutional representation, to engage with a less coherent entity. ${ }^{313}$ As with China-CELAC engagement, the European think tank CHOICE characterizes the $17+1$ as a "hub and spoke approach to "multinational bilateralism" 314

In recognition of China's attempt to use $17+1$ to "divide and conquer" Europe, the governments of the region have arguably begun to push back. In the February 2021 17+1 meeting, six members sent their Foreign Ministers rather than heads of State, despite heavy PRC lobbying to send their top executive. ${ }^{315}$

For Romania, within Eastern Europe, the political relationship with the PRC has been complex, with governments both courting it as an economic partner, while also pushing back. Romania's consciousness of the long-term threat from the PRC is arguably fueled by its own experience with dominance by an external Communist government, the nation's forced integration into a foreign economic

\footnotetext{
311 "IDB, China Eximbank further advance in the creation of equity investment platform for Latin America and the Caribbean," Interamerican Development Bank, March 19, 2012, https://www.iadb.org/en/news/newsreleases/2012-03-19/china-latin-america-equity-investment-fund,9894.html.

312 "Beijing faces scrutiny over clout at Latin American development bank," Financial Times, May 27, 2021, https://www.ft.com/content/e4bae811-8452-4f63-a1df-5baea103eaaf.

${ }^{313}$ Brînză, 2021.

314 “Empty Shell No More," 2020.

315 "Eastern Europe ends love fest with China amid Beijing-EU rift," 2021.
} 
system, and the suppression of discourse during the Communist period. As with other parts of Eastern Europe, that historical experience arguably has facilitated Romania's recognition of subtle PRC pressures, including the decision by Romanian President Klaus Iohannis not to personally attend the 2021 17+1 summit, despite considerable PRC pressures to do so. ${ }^{316}$

Complimenting Romania's recognition of the China threat, its government's attention to the renewed threat posed by Russia, as discussed previously, arguably helps make Romania and other East European states more receptive to the desires of the United States, due to its desire to maintain a strong bond with NATO. Indeed, Romania's hosting of a US base and an anti-ballistic missile shield against Russia further strengthens its incentives to maintain alignment with Washington, particularly on uses that impact its security partnership such as keeping its networks free of potentially compromising Chinese systems ${ }^{317}$, considerations not as directly relevant in the security calculations of most Latin American governments.

\section{EUROPE-LATIN AMERICA SYNERGIES REGARDING THE PRC}

Beyond the comparisons that can be made between Chinese engagement in Latin America and Europe, the dynamics of both are influenced by the economic and other interdependencies between the two regions as each engages the PRC. EU-based companies, for example, have a substantial position in Latin America, in sectors from petroleum to electricity transmission to manufacturing to logistics, and are thus impacted adversely by China's advance. They are also impacted positively by that advance, as partners in joint ventures with PRC-based companies, and beneficiaries where the Chinese have purchased stakes in those ventures from European firms.

European auto manufacturers such as Volkswagen and Mercedes, even while partnering with the Chinese elsewhere, are impacted by the advance of Chinese cars in competition for the Latin American market. Such competition includes numerous sectors, such as petroleum with Eni, Total and Shell, to telecommunications with Erikson and Telefonica (although both use Chinese equipment), to maritime logistics with Hapag-Lloyd and Maersk (including Hamburg Süd, which it has owned since May 2019). Competition between Chinese and European firms in Latin America also include Shanghai Dredging's displacement of Belgian firm Jan do Nul for a strategic contract to dredge the Paraguay-Paraguana river corridor. ${ }^{318}$ In banking in the region, Chinese firms such as China Construction Bank and ICBC compete to a degree with established European banks such as Spain's BBVA and Santander. European and Chinese firms also compete for the Latin American market in satellite development and

\footnotetext{
316 "Romania reveals the limits of China's reach in Europe," 2021.

317 Brînză, 2019.

318 "China competes in the dredging..." 2020.
} 
space launch, including Thales vying with Great Wall Industries Corporation (GWIC) to provide satellite launch services for countries such as Argentina and Chile.

Examples of partnerships between Chinese and European firms in Latin America, in the midst of such competition, include Sinopec's investment in Repsol's activities in the Brazilian petroleum sector, Sinochem's purchase of a $\$ 3.1$ billion stake in the Brazilian holdings of the Norwegian company Statoil ${ }^{319}$, State Grid's purchase of electricity transmission assets of AES in Brazil, and more recently its purchase of the Spanish company Naturgy's holdings in Chile. In construction, collaboration includes China Communications Construction Corporation's (CCCC) purchase of a 30\% stake in the Portuguese company Mota Engil, with multiple operations in Latin America. ${ }^{320}$

\section{CONCLUSIONS}

This work's examination of and comparison of Chinese engagement in Latin America and Europe holds lessons for Romania, even while Romanian engagement with the PRC presents insights for the rest of Europe, Latin America, and the US as it seeks to respond to China's global activities.

For Romania, the patterns discussed in this paper suggest that PRC pursuit of Romanian agricultural goods and markets for strategic sectors such as 5G and nuclear energy are consistent with China's behavior globally.

The patterns of Chinese engagement beyond Romania, in both Latin America and Europe, suggests that PRC influence, through the lure of its loans, investments, purchasing power and partnerships, and augmented by the role of the Chinese government in putting together cross sector deals, heightens the importance of those countries to engage with the PRC and its companies through a framework of transparency, national planning, strong institutions, and enforcement of national laws.

The experience of Latin America and Europe further suggests that the longrun danger of generally economically-oriented PRC influence goes beyond the accumulation of benefit to PRC-based SOEs and other Chinese actors over domestic ones with respect to who gets the biggest part of the value added from economic activities. This study suggests a danger, found in both regions to varying degrees, to the long-term freedom of expression domestically and internationally. It similarly suggests a long-term tendency from engagement with the PRC toward corruption, the erosion of democratic institutions, and the consolidation of power by authoritarian governments aligned with the PRC.

\footnotetext{
319 "Sinochem to become 40\% partner of Statoil in Peregrino Oil Field in Brazil," Sinochem official website, May 22, 2010, http://www.sinochem.com/en/s/1569-5518-17446.html.

320 Mat Youkee, "Chinese expansion with a Portuguese face," Dialogo Chino, November 20, 2020, https://dialogochino.net/en/infrastructure/38445-cccc-mota-engil-chinese-expansion-with-a-portuguese-face/.
} 
For Latin America and other parts of Europe, Romania's push back against the PRC in both specific projects and political engagements and expressions, emphasizes the importance of a shared understanding within the society and the country's political leadership and economic elites, regarding the subtle, but very real risks of compromising seemingly abstract principles of a society's political and economic system for the short-term benefits offered by China. For countries across both Latin America and Europe, in the context of immediate economic need, holding true to abstract ideals such as transparency, good governance, a level playing field, the rule of law and free expression can seem frivolous and idealistic.

For the states of Latin America and Western Europe, without as palpable a history of past repression and immediate security threats, the sacrifices that help stop the erosion of a nation's economic and political fabric are hard to defend. For the rest of Europe, Latin America, and the global community, it is important to continue to explore and articulate Romania's perspective toward the PRC, even while continuing to be a good partner to Romania itself. Doing so is fundamental to ensure that, despite Romania's caution and resistance to the corrosive effects of PRC engagement, the country is not ultimately compromised by it.

\section{BIBLIOGRAPHY}

- Amaro S., "China bought most of Greece's main port and now it wants to make it the biggest in Europe," CNBC, November 15, 2019, https://www.cnbc.com/2019/11/15/china-wants-to-turn-greece-piraeus-portinto-europe-biggest.html.

- Arminas D., "Chile awards CRCC major Talca-Chillán upgrade," World Highways, April 14, 2021, https://www.worldhighways.com/wh12/ news/chile-awards-crcc-major-talca-chillan-upgrade.

- Ayres M., "China to announce billion-dollar investment in Brazilian port of Sao Luis: sources," Reuters, November 13, 2019, https://www.reuters.com/ article/us-brazil-brics-china-investment/china-to-announce-billion-dollarinvestment-in-brazilian-port-of-sao-luis-sources-idUSKBN1XN2NM.

- Barkin N., Vasovic A., "Chinese 'highway to nowhere' haunts Montenegro," Reuters, July 16, 2018, https://www.reuters.com/article/us-china-silkroadeurope-montenegro-insi-idUSKBN1K60QX.

- "Beijing faces scrutiny over clout at Latin American development bank," Financial Times, May 27, 2021, https://www.ft.com/content/e4bae811-84524f63-a1df-5baea103eaaf.

- "Belt and Road reality check: How to assess China's investment in Eastern Europe," MERICS, July 10, 2019, https://merics.org/en/analysis/belt-androad-reality-check-how-assess-chinas-investment-eastern-europe. 
- Bieliński T., Markiewicz M., Oziewicz E., "Do Central and Eastern Europe Countries Play a Role in the Belt and Road Initiative? The Case of Chinese OFDI into the CEE-16," Comparative Economic Research, Central and Eastern Europe, Volume 22, Number 2, 2019, http://doi.org/10.2478/cer2019-0009.

- Blake E., "Chinese Military Seeks Jungle Warfare Training From Brazil," International Business Times, August 10, 2015, https://www.ibtimes.com/ chinesemilitary-seeks-jungle-warfare-training-brazil-2046473.

- "Brazil's Bolsonaro to allow China's Huawei in 5G auctions: newspaper," Reuters, January 16, 2021, https://www.reuters.com/article/us-brazil-huaweitech-idUSKBN29L0JM.

- Brînză A., "How China's 17+1 Became a Zombie Mechanism," The Diplomat, February 10, 2021, https://thediplomat.com/2021/02/how-chinas171-became-a-zombie-mechanism/.

- Brînză A., "How the US-China Competition Is Playing out in Romania," The Diplomat, November 1, 2019, https://thediplomat.com/2019/11/how-the-uschina-competition-is-playing-out-in-romania/.

- "Central and Eastern European Regional Center of Confucius Institute," Official Website, Accessed June 3, 2021, http://confucius-institutes.eu/ index.php?r=site/about.

- "China is making substantial investment in ports and pipelines worldwide," The Economist, February 6, 2020, https://www.economist.com/specialreport/2020/02/06/china-is-making-substantial-investment-in-ports-andpipelines-worldwide.

- "China-Central and Eastern Europe Investment Cooperation Fund, Official Website, Accessed June 3, 2021, http://china-ceefund.com/.

- "China competes in the dredging of Paraguay/Parana Waterway which handles 90 million tons of grains," Mercopress, November 25, 2020, https://en.mercopress.com/2020/11/25/china-competes-in-the-dredging-ofparaguay-parana-waterway-which-handles-90-million-tons-of-grains\#: : text=A\%20Chinese $\% 20$ company $\% 20$ entered $\% 20$ the,river $\% 20$ course $\% 20$ be ginning\%20in\%202021.

- "China, Hungary to strengthen military cooperation," CGTN, March 25, 2021, https://newseu.cgtn.com/news/2021-03-25/China-s-Defense-Minister-visitsBudapest-for-official-talks-YU5IRPv8NG/index.html.

- "China's SGCC offers to construct HidroAysen power line," Global Transmission Report, January 4, 2012, https://www.globaltransmission. info/archive.php?id=10056.

- "China Yangtze Power completed its acquisition of Peruvian power company, Luz Del Sur," BN Americas, April 24, 2020, https://www.bnamericas.com/ 
en/news/china-yangtze-power-completed-its-acquisition-of-peruvian-powercompany-luz-del-sur.

- "Chinese firm takes over Kingston Freeport management company," Stabroek News, April 25, 2020, https://www.stabroeknews.com/2020/04/25/news/ regional/jamaica/chinese-firm-takes-over-kingston-freeport-managementcompany/.

- "Chinese duo to build 1.1-GW solar power plant in Brazil," Renewables Now, April 29, 2021, https://renewablesnow.com/news/chinese-duo-to-build-11gw-solar-power-plant-in-brazil-739550/.

- "Chinese investment fund expands into Romanian agriculture," Romania Insider, September 27, 2019, https://www.romania-insider.com/chinese-fundromanian-agriculture.

- "Chinese Solar Company Expanding to Eastern Europe," Eastern Europe Business News, February 16, 2018, http://www.eebusiness.net/chinese-solarcompany-expanding-to-eastern-europe.

- "Chinese vessel coming to Trinidad," Jamaica Observer, February 25, 2014, https://www.jamaicaobserver.com/news/Chinese-vessel-coming-to-Trinidad.

- Colqui L., "Jujuy. Cauchari: el parque solar más grande de América Latina comenzó a vender energía al país," La Nacion, September 26, 2020, https://www.lanacion.com.ar/economia/jujuy-cauchari-parque-solar-masgrande-america-nid2461924/.

- "Confucius Institutes Around the World," Dig Mandarin, Accessed June 3, 2021, https://www.digmandarin.com/confucius-institutes-around-theworld.html.

- "Cosco sees 2020 construction start for US\$3bn Chancay port," BNAmericas, June 26, 2019, https://www.bnamericas.com/en/news/cosco-sees-2020construction-start-for-us3bn-chancay-port.

- Diamante S., "La energía nuclear, una herencia a resolver con China," La Nacion, January 22, 2020, https://www.lanacion.com.ar/economia/la-energianuclear-una-herencia-a-resolver-con-china-nid2326138/.

- "Eastern Europe ends love fest with China amid Beijing-EU rift," Nikkei Asia, May 28, 2021, https://asia.nikkei.com/Politics/International-relations/ Eastern-Europe-ends-love-fest-with-China-amid-Beijing-EU-rift.

- "Empty Shell No More: China's Growing Footprint In Central and Eastern Europe," China Observers in Central and Eastern Europe (CHOICE), Ivana Karásková, Ed., April 2020, https://chinaobservers.eu/new-publicationempty-shell-no-more-chinas-growing-footprint-in-central-and-easterneurope/.

- Ellis E.R., "China's Bid to Dominate Electrical Connectivity in Latin America," China Brief, Vol. 21, Issue 10, May 21, 2021, 
https://jamestown.org/program/chinas-bid-to-dominate-electricalconnectivity-in-latin-america/.

- Ellis E.R., "China's Diplomatic and Political Approach in Latin America and the Caribbean," Testimony before the US-China Economic and Security Review Commission, May 20, 2021, https://www.uscc.gov/sites/default/ files/2021-05/Evan_Ellis_Testimony.pdf.

- Ellis E.R., "Chinese Advances in Chile," Global Americans, March 2, 2021, https://theglobalamericans.org/2021/03/chinese-advances-in-chile/.

- Ellis E.R., "Chinese Engagement in Latin America in the Context of Strategic Competition with the United States," Testimony to the U.S.-China Economic and Security Review Commission, June 24, 2020, https://www.uscc.gov/ sites/default/files/2020-06/Ellis_Testimony.pdf.

- Ellis E.R., "Chinese Security Engagement in Latin America," Center for Strategic and International Studies, November 2020, https://www.csis.org/ analysis/chinese-security-engagement-latin-america.

- Ellis E.R., "New Directions in the Deepening of China-Argentine Engagement," Global Americans, February 11, 2021, https://theglobal americans.org/2021/02/new-directions-in-the-deepening-chinese-argentineengagement/.

- Ellis E.R., "Peru's Multidimensional Challenge - Part 3: engagement with China," Global Americans, November 20, 2020, https://theglobal americans.org/2020/11/perus-multidimensional-challenge-part-3engagement-with-china/.

- Ellis E.R., "The Evolution of Chinese Soft Power in Latin America," in Soft Power with Chinese Characteristics, Kingsley Edney, Stan Rosen, and Ying Zhu, Eds. (Milton Park, England: Routledge, 2020).

- Ellis E.R., "Why China's Advance in Latin America Matters," National Defense, January 27, 2021, https://www.realcleardefense.com/2021/ 01/27/why_chinas_advance_in_latin_america_matters_658054.html.

- Fick J., "Perenco's Brazil Unit to Sell 10\% Stake in Offshore Blocks to Sinochem," The Wall Street Journal, January 8, 2012, https://www.wsj.com/articles/SB10001424052970204257504577148443070 091790.

- "Ganfeng Lithium increases stake in Bacanora's Sonora project to 50\%," Reuters, November 13, 2020, https://www.reuters.com/article/bacanoralithium-ganfeng/ganfeng-lithium-increases-stake-in-bacanoras-sonoraproject-to-50-idUSL8N2HZ54S.

- Giolzetti D., "China's Front Door to America's Backyard," The Diplomat, June 28, 2019, https://thediplomat.com/2019/06/chinas-front-door-toamericas-backyard/.I 
- Gold H., "UK bans Huawei from its 5G network in rapid about-face," CNN, July 14, 2020, https://www.cnn.com/2020/07/14/tech/huawei-uk-ban/ index.html.

- 'Greece 'Appreciates' Joining China's Belt and Road Initiative," TeleSur, May 16, 2019, https://www.telesurenglish.net/news/Greece-AppreciatesJoining-Chinas-Belt-and-Road-Initiative-201905150022.html\#: :text=The\%20Greek\%20economy\%20has\%20benefited $\% 20$ fro $\mathrm{m} \% 20$ joining $\% 20$ China\%E2\%80\%99s, the $\% 20$ few $\% 20$ EU\%20countries $\% 2$ 0to\%20join\%20the\%20movement.

- Hua J., Xu W., Wills K., "Sinopec signs \$3.5 billion deal for Galp's Brazil oil asset," Reuters, November 11, 2011, https://www.reuters.com/article/us-galpbrazil-sale/sinopec-signs-3-5-billion-deal-for-galps-brazil-oil-assetidUSTRE7AA0ZF20111111.

- Hutt D.M, Turcsányi R.Q., "No, China Has Not Bought Central and Eastern Europe," Foreign Policy, May 27, 2020, https://foreignpolicy.com/2020/ 05/27/china-has-not-bought-central-eastern-europe/.

- "IDB, China Eximbank further advance in the creation of equity investment platform for Latin America and the Caribbean," Interamerican Development Bank, March 19, 2012, https://www.iadb.org/en/news/news-releases/201203-19/china-latin-america-equity-investment-fund,9894.html.

- "Integrantes del Ejército Chino se entrenan en Colombia como Tiradores de Alta Precisión," FuerzasMilitares, October 23, 2016, http://www.fuerzas militares.org/notas/colombia/ejercito-nacional/7145-tap-50.html.

- de la Jara A., "Tianqi buys stake in lithium miner SQM from Nutrien for $\$ 4.1$ billion," Reuters, December 3, 2018, https://www.reuters.com/article/uschile-tianqi-lithium-idUSKBN1O217F.

- Jemio M.T., "Bolivia rethinks how to industrialize its lithium amid political transition," Dialogo Chino, May 19, 2020, https://dialogochino.net/ en/extractive-industries/35423-bolivia-rethinks-how-to-industrialize-itslithium-amid-political-transition/.

- Kakissis J., "Chinese Firms Now Hold Stakes In Over A Dozen European Ports,” NPR, October 9, 2018, https://www.npr.org/2018/10/09/642587456/ chinese-firms-now-hold-stakes-in-over-a-dozen-european-ports.

- Kinch D., "Chinese Steelmakers Buy Into Brazil's CBMM," The Wall Street Journal, September 2, 2011, https://www.wsj.com/articles/ SB10001424053111904583204576546890451706256.

- Labrut M., "DP World launches construction of deepwater port in Posorja, Ecuador," Seatrade Maritime News, September 28, 2017, https://www.seatrade-maritime.com/americas/dp-world-launchesconstruction-deepwater-port-posorja-ecuador. 
- Lau S., "China's Eastern Europe strategy gets the cold shoulder," Politico, February 9, 2021, https://www.politico.eu/article/china-xi-jinping-easterneurope-trade-agriculture-strategy-gets-the-cold-shoulder/.

- Matura T., "Chinese Investment in Central and Eastern Europe: A reality check," CEECAS, April 21, 2021, https://www.china-cee-investment.org/.

- Milenkovic A., "China and Serbia strengthening military ties," CGTN, March 27, 2021, https://newseu.cgtn.com/news/2021-03-27/China-and-Serbiastrengthening-military-ties-YYwwasXdCM/index.html.

- Muller R., "China sidelined for Czech nuclear tender, Russia still in play," Reuters, January 27, 2021, https://www.reuters.com/world/china/chinasidelined-czech-nuclear-tender-russia-still-play-2021-01-27/.

- Nixon A., "China's Growing Arms Sales to Latin America," The Diplomat, August 24, 2016, https://thediplomat.com/2016/08/chinas-growing-armssales-to-latin-america/.

- Ouerghi D., "China's Ganfeng completes majority stake acquisition in Argentina lithium project," Metals Bulletin, August 28, 2020, https://www.metalbulletin.com/Article/3948479/Chinas-Ganfeng-completesmajority-stake-acquisition-in-Argentina-lithium-project.html.

- "Peru selecciona el sistema táctico de lanzacohetes múltiples Norinco tipo 90B," Infodefensa, October 1, 2014, https://www.infodefensa.com/ latam/2014/01/10/noticia-selecciona-sistema-tactico-lanzacohetes-multiplesnorinco.html.

- "Regulador chileno aprueba sin condiciones compra de eléctrica CGE por china State Grid," Reuters, March 31, 2021, https://www.infobae.com/ america/agencias/2021/03/31/regulador-chileno-aprueba-sin-condicionescompra-de-electrica-cge-por-china-state-grid-2/.

- "Romania reveals the limits of China's reach in Europe," Politico, May 3, 2021, https://www.politico.eu/article/romania-recoils-from-china-aggressivediplomacy/.

- "Serbian purchase of missile defence system shows ties deepening with China," Reuters, August 3, 2020, https://www.reuters.com/article/us-serbiaarms-china-idUSKBN24Z171.

- "Sinochem to become 40\% partner of Statoil in Peregrino Oil Field in Brazil," Sinochem official website, May 22, 2010, http://www.sinochem.com/ en/s/1569-5518-17446.html.

- Spring J., "Hands off Brazil's niobium: Bolsonaro sees China as threat to utopian vision," Reuters, October 25, 2018, https://www.reuters.com/article/ us-brazil-election-china-niobium/hands-off-brazils-niobium-bolsonaro-seeschina-as-threat-to-utopian-vision-idUSKCN1MZ1JN. 
- "UTE firmó contrato para el cierre del anillo de transmisión del norte, obra clave en el período," El Pais, May 31, 2021, https://negocios.elpais.com.uy/ ute-firmo-contrato-cierre-anillo-transmision-norte-obra-clave-periodo.html.

- Valencia J., "By building Bogotá metro, China makes a new breakthrough in Latin America," PRI, November 5, 2020, https://www.pri.org/stories/202011-05/building-bogot-metro-china-makes-new-breakthrough-latin-america.

- Youkee M., "Chinese expansion with a Portuguese face," Dialogo Chino, November 20, 2020, https://dialogochino.net/en/infrastructure/38445-ccccmota-engil-chinese-expansion-with-a-portuguese-face/. 